Bangladesh Journal of Anatomy January 2011, Vol. 9 No. 1 pp 41-44

\title{
Histological Study on Thickness of Different Layers of the Gallbladder- A Postmortem Study
}

\author{
Nurun Nahar ${ }^{1}$, Shamim Ara $^{2}$, Fatema Zohora ${ }^{3}$, Dilruba Siddika ${ }^{4}$, Tahamida Yesmin $^{5}$
}

\begin{abstract}
Context: Pathological process in the gallbladder occur commonly in association with ageing and includes cholelithiasis, cholecystitis and gallbladder carinoma. Detailed histological knowledge will help surgeon, sonologist and pathologist to adopt appropriate plan for diagnosis and treatment of gallbladder disease.
\end{abstract}

Study type: Descriptive type of study.

Place and period of study: Department of Anatomy, Dhaka Medical College, Dhaka from November 2008 to April 2009.

Materials: 70 post mortem human gallbladder were collected from unclaimed dead bodies that were under examination in the department of Forensic Medicine of Dhaka Medical College, Dhaka.

Method: The samples were divided into three age groups i.e. group A (10-20 years), Group B (21-40 years), group C (41-60 years). Histological study was carried out on relatively 20 fresh samples.

Result: The mean thickness of the mucosal layer ranges from $0.403 \pm 0.004$ to $0.428 \pm 0.010 \mathrm{~mm}$, fibromuscular layer ranges from $0.933 \pm 0.012$ to $0.948 \pm 0.003 \mathrm{~mm}$ and the serosal layer ranges from $0.397 \pm 0.006$ to $0.425 \pm 0.018 \mathrm{~mm}$. Statistically significant positive correlation $(p<0.001)$ was found between age and thickness of different layer of gallbladder. There was no statistically significant sex difference was found in between any age group.

Conclusion: There was change in thickness of different layers of gallbladder in relation to age.

Key words: Gallbladder, Histology, Thickness.

\section{Introduction:}

The gallbladder is a slate- blue piriform sac partly sank in a fossa inferior surface of the right hepatic lobe $^{1}$. The wall of the gallbladder consists of a mucosa composed of simple columnar epithelium and lamina propria, a layer of smooth muscle , a perimuscular connective tissue layer, and a serous membrane ${ }^{2}$. The mucosa consist of simple columnar

1. Assistant Professor, Department of Anatomy, Ad-din Women's Medical College, Dhaka.

2. Professor and Head, Department of Anatomy, Dhaka Medical College, Dhaka.

3. Assistant Professor (c.c.), Department of Anatomy, Faridpur Medical College.

4. Assistant Professor, Department of Anatomy, Ibn Sina Medical College, Dhaka.

5. Assistant Professor, Department of Anatomy, Z. H. Sikder Women's Medical College, Dhaka.

Correspondence: Nurun Nahar ${ }^{1}$ epithelium and a lamina propria of loose connective tissue $^{3}$. The muscle layer of the gallbladder wall is an irregular loose network of longitudinal transverse and oblique bundle of smooth muscle cells. The space between the bundles are occupied by collagenous and elastic fibers occasionally by the fibroblasts ${ }^{4}$. The adventitia is composed of collagen and elastic fibers. The adventitial connective tissue also contain a rich lymphatic network ${ }^{1}$. The gallbladder disorders is a common health problem, common disorders are cholelithiasis, cholecystitis, gallbladder cancer ${ }^{5}$. The commonest lesion observed is chronic cholecystitis (80\%) followed by acute cholecystitis (9.3\%), invasive carcinoma (7.3\%), carcinoma in situ(0.6\%) and dysplasia(0.6\%) (Nadeem et al. 2000) ${ }^{6}$. Thickness of the gallbladder wall is a common though 
nonspecific findings of gallbladder disease. Abnormal thickness can be attributed to disease that is intrinsic to the gallbladder?

\section{Materials and methods:}

The samples of human gallbladder were collected from unclaimed dead bodies that were under examination in the department of Forensic Medicine of Dhaka Medical College, Dhaka from November 2008 to April 2009. The collected samples were divided into three groups (according to Habiba $2001^{7}$ ).

\section{Table-I}

Age and sex distribution of different groups

\begin{tabular}{lccc}
\hline Group & Age in years & \multicolumn{2}{c}{ No of samples } \\
& & Male & Female \\
\hline A & $10-20$ & 3 & 5 \\
B & $21-40$ & 20 & 14 \\
C & $41-60$ & 16 & 12 \\
\hline
\end{tabular}

A. Preparation of slide for histological study:

For the histological study, from group A, B \& C 5, $10 \& 5$ samples were taken respectively. The tissue blocks of the gallbladder were fixed in $10 \%$ formol saline in a plastic container. The tissue were washed in running tap water, dehydration was done with ascending grades of alcohol, cleared with xylene, infiltrated and embedded in paraffin. Paraffin blocks were cut at 5 micrometer thickness and were stained with routine Harris' Haematoxylin and Eosin ( H\&E) stain.

B. Measurement of the thickness of different layers of the gallbladder:

Under the light microscope, 5 best slides from group A, 10 slides from group B and 5 slides from group $C$ were examined. The thickness of the layers of the gallbladder were estimated by using the ocular micrometer. In each slide, the measurement was done at 3 points and the average value was recorded (at $x 10$ objective and $\times 10$ eye piece). The thickness of each layer was measured by estimation of how many smallest division of the ocular micrometer were occupied by each layer respectively. The stage micrometer calibration was focussed under the objective to be used and the ocular micrometer calibration was superimposed on them in such a way that starting mark on the ocular micrometer matched exactly with a starting mark on the stage $\mu \mathrm{m}$ than the mark on the stage and ocular micrometer that corresponds to each other most closely was noted. In this way determination of how many of the smallest division of the ocular micrometer corresponds to how many smallest division of the stage micrometer was done (Fig.1)

\section{Results:}

In the present study, the mean \pm SD thickness of the mucosal layer ranges from $0.403 \pm 0.004$ to $0.428 \pm 0.010 \mathrm{~mm}$, fibromuscular layer ranges from $0.933 \pm 0.012$ to $0.948 \pm 0.003 \mathrm{~mm}$ and the serosal layer ranges from $0.397 \pm 0.006$ to $0.425 \pm 0.018 \mathrm{~mm}$. In the mucosal layer of the gallbladder, the difference between group A and B ( $p<0.001$ in female) was statistically significant. In serosal layer of the gallbladder, the difference between group $A \& B(p<$ 0.01 in male, $P<0.05$ in both sexes) and group $B$ \& $C(p<0.05$ in both sexes) was statistically significant (Fig.2) (Tab-II).

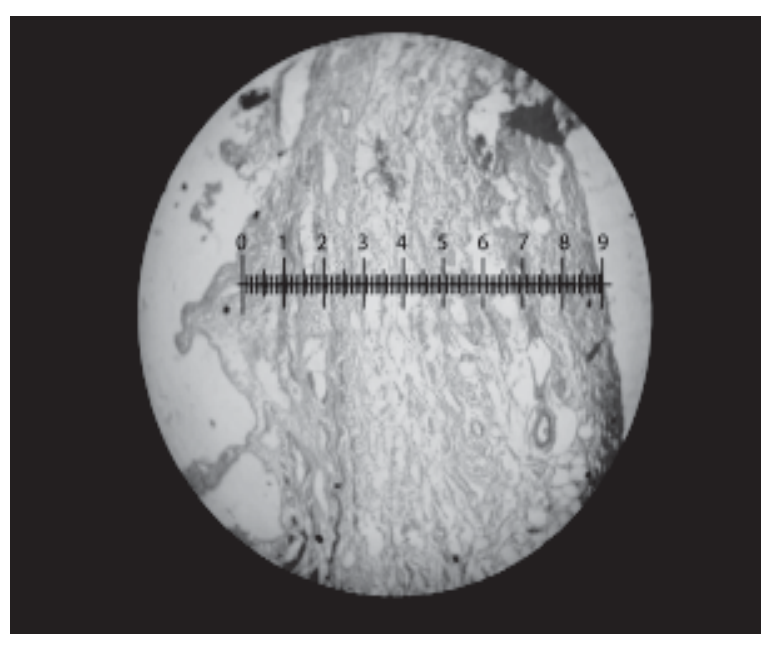

Fig.-1: Scale showing measurement of different layer of gallbladder 
Bangladesh J. Anat. 2011; 9(1) : 41-44

Table -II

Thickness of three layers of male and female gallbladder in different age groups

\begin{tabular}{|c|c|c|c|c|c|c|}
\hline \multirow{4}{*}{$\begin{array}{l}\text { Age } \\
\text { group }\end{array}$} & \multicolumn{6}{|c|}{ Thickness (mm) } \\
\hline & \multicolumn{3}{|c|}{ Male } & \multicolumn{3}{|c|}{ Female } \\
\hline & Mucosa & Fibromuscular & Serosa & Mucosa & Fibromuscular & Serosa \\
\hline & Mean + SD & Mean+SD & Mean+SD & Mean +SD & Mean+SD & Mean+SD \\
\hline \multirow[t]{3}{*}{$\bar{A}$} & $0.403+0.004$ & $0.944+0.002$ & $0.402+0.000$ & $0.407 .+0.004$ & $0.94+0.003$ & $0.402+0.003$ \\
\hline & $(0.400-0.405)$ & $(0.942-0.945)$ & $(0.402-0.402)$ & $(0.405-0.412)$ & $(0.940-0.945)$ & $(0.400-0.405)$ \\
\hline & $\mathrm{n}=2$ & $\mathrm{n}=2$ & $\mathrm{n}=2$ & $n=3$ & $n=3$ & $n=3$ \\
\hline \multirow[t]{3}{*}{ B } & $0.419+0.010$ & $0.948+0.003$ & $0.416+0.004$ & $0.428+0.010$ & $0.945+0.009$ & $0.425+0.01$ \\
\hline & $(0.405-0.430)$ & $(0.945-0.950)$ & $(0.411-0.420)$ & $(0.410-0.435)$ & $(0.930-0.955)$ & $(0.405-0.445)$ \\
\hline & $n=5$ & $n=5$ & $n=5$ & $n=0$ & $\mathrm{n}=0$ & $n=5$ \\
\hline \multirow[t]{3}{*}{ C } & $0.410+0.014$ & $0.933+0.018$ & $0.405+0.000$ & $0.412+0.013$ & $0.933+0.012$ & $0.397+0.006$ \\
\hline & $(0.400-0.420)$ & $(0.920+0.945)$ & $(0.405-0.405)$ & $(0.405-0.405)$ & $(0.09200-0.920)$ & $(0.390-0.400)$ \\
\hline & $\mathrm{n}=2$ & $n=2$ & $\mathrm{n}=2$ & $n=3$ & $n=3$ & $n=3$ \\
\hline
\end{tabular}

Figures in parentheses indicate range.

Group A Age 10-20 years

Group B Age 21-40 years

Group C Age; 41-60 years

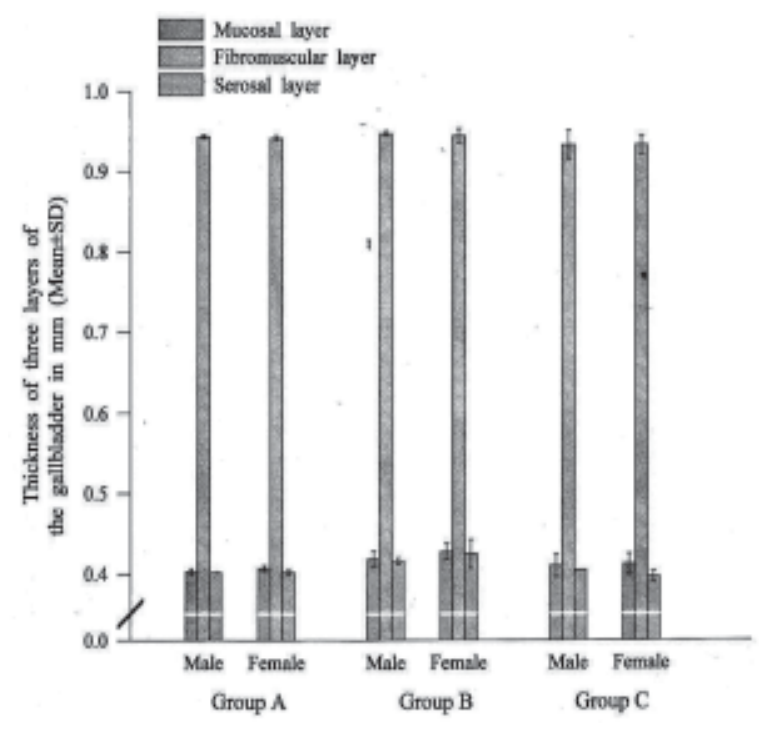

Group A Age 10-20 years

Group B Age 21-40 years

Group C Age; 41-60 years

Fig.-2: Thickness of three layers of male and female gallbladder in different age group.

\section{Discussion:}

In the present study, the mean \pm SD thickness of the mucosal layer of the gallbladder in male was $0.403 \pm 0.004 \mathrm{~mm}$ in group $\mathrm{A}, 0.419 \pm 0.010 \mathrm{~mm}$ in group $B$ and $0.410 \pm 0.014 \mathrm{~mm}$ in group $C$. In female the mean \pm SD thickness of the mucosal layer of the gallbladder in female was $0.407 \pm 0.004 \mathrm{~mm}$ in group $A, 0.428 \pm 0.010 \mathrm{~mm}$ in group $B$ and $0.412 \pm$ $0.013 \mathrm{~mm}$ in group $\mathrm{C}$. Khalil $\mathrm{M}^{8}$ observed that the minimum, maximum and mean thickness of the mucosa were $0.432 \mathrm{~mm}, 1.1 \mathrm{~mm}$ and $0.766 \mathrm{~mm}$ respectively. The result of the present study is similar with that of minimal thickness of Khalil M. C U Cotton and $L$ Reuss ${ }^{9}$ found that the mucosal unstirred layer thickness was $0.700 \mathrm{~mm}$, which is higher than that of present study.

\section{References:}

1. Neil R Borly, editor. Hepatobiliary system. In; Standring S, Ellis H, Healy GC, Johnson D, WilliamsA, Collins P, et al. editors. Gray's anatomy. $39^{\text {th }}$ ed.London: Elsevier Churchill Livingstone; 2005. 1227-9. 
2. Junqueira LC, Carnerio J, Kelly RO. Basic histology. $11^{\text {th }}$ ed .California: Lange Medical publications; 2005. 344-5.

3. Ross MH, Kaye JI, Pawlina W. Histology. $6^{\text {th }}$ ed. Philadelphia; Lippincott Williams \& Wilkins; 2003. 479-82.

4. Fawcett DW. a textbook of histology. $12^{\text {th }}$ ed. New York: Chapman \& Hall; 1994. 677-9.

5. Kumar V, Abbas AK, Fausto N. Pathologic basis of disease. $7^{\text {th }}$ ed. New Delhi: W.B. Saundars company; 2005. 927-9.
6. Nadeem I, Nagi A H. Morphological profile of gallbladder disease. J Rawal Med Coll 2004; $4^{\text {th }}(1-2): 30-3$.

7. Habiba AC . Roll of preoperative ultrasound measure of gallbladder wall thickness in predicting laparoscopic operablility (M phil. thesis). Dhaka: University of Dhaka; 2001.

8. Khali M. A comparative anatomical study of the extra-hepatic biliary apparatus in goat, cow and man (M phil thesis).Dhaka: University of Dhaka.

9. Cotton $\mathrm{CU}$, Reuss L. Measurement of the effective of the mucosal umstirred layer in Necturus gallbladder epithelium. J Genthysiol 1989; 93(4): 631-47. 